BRIEF REPORT

\title{
Children's bicycle helmet use and injuries in Hillsborough County, Florida before and after helmet legislation
}

\author{
K D Liller, J Nearns, M Cabrera, B Joly, V Noland, R McDermott
}

Injury Prevention 2003;9:177-179

See end of article for authors' affiliations

\section{Correspondence to:}

Associate Professor Karen DeSafey Liller, University of South Florida College of

Public Health, 13201

Bruce B Downs Blvd

Tampa, FL 33612, USA;

kliller@hsc.usf.edu
The purpose of this research was to explore the changes in children's bicycle helmet use and motor vehicle bicycle related injuries in Hillsborough County, Florida before and after passage of the Florida's bicycle helmet law for children under the age of 16. The results show a significant increase in bicycle helmet use among children, ages 5-13, in the post-law years compared with the pre-law years. Also, there has been a significant decline in the rates of bicycle related motor vehicle injuries among children in the post-law years compared with the pre-law years. Although there have been complementary educational and outreach activities in the county to support helmet use, it appears that the greatest increase in use occurred after the passage of the helmet law. It is recommended that educational efforts continue to sustain helmet use rates and decreases in injuries.
$\mathrm{R}$ esearch has shown that bicycle helmets effectively prevent head and brain injuries and related deaths. A recent meta-analytic report on helmets showed a summary odds ratio efficacy of $0.40,0.42,0.53$, and 0.27 for head, brain, facial, and fatal injuries, respectively.

Legislation may be important in increasing bicycle helmet use. ${ }^{2}$ The increase in average probability of helmet wearing in mandated helmet states was $18.4 \%,{ }^{4}$ and in 2002, 20 states had such laws, all applying to individuals under age $18 .^{5}$

In 1997 a Florida law adopted in 65 of 67 counties required that riders under 16 wear a helmet. A 1999 Florida study showed that children riding bicycles where the law was in effect were twice as likely to wear helmets as those in non-participating counties. ${ }^{6}$ The relationship between the Florida legislation and bicycle related injuries is unknown.

\section{METHODS}

Since 1993, observations of helmet use in children 5-13 have been conducted in Hillsborough County, Florida (population 998 948). This age group includes those most likely to experience bicycle related injuries. ${ }^{7}$

Observation protocols followed guidelines established by the Harborview Injury Prevention and Research Center. ${ }^{8}$ Key issues were':

(1) Observers always obtained study approval through the county sheriff's office.

(2) Youth showing obvious signs of puberty were excluded from the study.

(3) Children's bicycles could not be equipped with training wheels and the helmet must have been observed on the head or being removed from the head.

(4) Observation times (non-school settings) were limited to $\leqslant 20$ minutes at any one site to avoid duplicate counts. At schools, observers were positioned at bike racks during the observation period.

(5) All observers were trained for one or more days. Inter-rater reliability consistently exceeded $90 \%$.

County census tracts $(n=167)$ were divided into two ordinal lists stratified by income and the population of children, ages $0-14 .{ }^{9}$ Each of these lists was divided into deciles of approximately 17 tracts each. Three tracts were selected randomly from each decile- a total of 60 tracts with at least two observations sites chosen from each. Approximately 120 observa- tion sites were used-schools, playground areas, parks, bike paths, and intersections. Observations occurred 2-3 times per week, February through May and included helmet use, gender, race/ethnicity, and helmet use of companions. Approximately 400 children were observed each year.

Age specific rates of bicycle related injuries or deaths involving a motor vehicle in the pre-law and post-law years were obtained from the Florida Department of Transportation and other state agencies. These data were used because collisions with motor vehicles account for the most serious bicycle injuries and more death $\mathrm{s}^{10}$ and lack of consistent $\mathrm{E}$ coding of hospital discharge and emergency department data. Police complete crash reports at the site and evaluate the victim as sustaining no injury, possible injury, non-incapacitating injury, incapacitating injury, and a fatality. Helmet use also is recorded. Descriptive statistics, cross tabulations, $\chi^{2}$ analyses, and trend analyses with model fitting were used to analyze the helmet use and injury data and to determine statistical significance. To determine the internal validity of our findings, state data were used to compare injuries before and after law enactment. These data were appropriate for comparison purposes since both sources use the same motor vehicle crash data for injury status determination. Such similarity does not occur with state hospital discharge data or national data that use emergency room reports. This study was approved by the University of South Florida Institutional Review Board.

\section{RESULTS}

Helmet use data are shown in table 1 and bicycle related injuries and rates in the pre-law and post-law years are shown in table 2. Although the helmet law only applies to children under 16, the data provided by the state are grouped into ages $0-4,5-9$, and 10-14. Most observations were of children in these age ranges since we excluded physically mature youth.

Helmet use was greater among children in the highest income tracts, white, and who rode with helmeted companions $(\mathrm{p}<0.05)$. Helmet use significantly increased from 3.6\% in 1993 to $67.0 \%$ in 1998 (odds ratio (OR) 55.2: 95\% confidence interval (CI) 36.1 to 84.5). The odds of children wearing a helmet in 1997, the year the law went into effect,

Abbreviations: $\mathrm{Cl}$, confidence interval; $\mathrm{OR}$, odds ratio 


\begin{tabular}{|ll|}
\hline \multicolumn{2}{|l|}{$\begin{array}{l}\text { Table } 1 \\
\text { use observed, Hillsborough County, }\end{array}$} \\
Florida, & 1993-2000 \\
\hline Year & $\%$ Helmet user \\
\hline 1993 & 3.6 \\
1994 & Observational data unavailable \\
1995 & 5.5 \\
1996 & 14.0 \\
$1997 *$ & 57.0 \\
1998 & 67.0 \\
1999 & 55.9 \\
2000 & 50.1 \\
\hline *Legislation year. \\
\hline
\end{tabular}

Table 2 Numbers and rates of motor vehicle related bicycle rider injury, Hillsborough County, Florida, 1993-2000, ages 0-14 years

\begin{tabular}{lll}
\hline Year & $\begin{array}{l}\text { No of motor vehicle } \\
\text { bicycle injuries }\end{array}$ & $\begin{array}{l}\text { Rate per } \\
100000\end{array}$ \\
\hline 1993 & 135 & 73.7 \\
1994 & 125 & 66.7 \\
1995 & 140 & 73.4 \\
1996 & 125 & 64.8 \\
$1997^{*}$ & 100 & 51.1 \\
1998 & 77 & 39.1 \\
1999 & 101 & 50.3 \\
2000 & 87 & 40.8 \\
\hline \multirow{2}{*}{ *Legislation year. }
\end{tabular}

were eight times greater than in the preceding year (OR 8.3; 95\% CI 6.1 to 11.4). Although there were declines in 1999 $(p=0.001)$ and in 2000 (table 1), measurement error cannot be ruled out. ${ }^{11}$ A clear increase is seen in helmet use post-legislation compared with pre-legislation, from an average of $7.7 \%$ during the pre-law years (1993-96) to $57.5 \%$ during the post-law years (1997-2000). Trend tests reveal that this increase $(\mathrm{p}<0.0001)$ exceeds secular expectations indicated by the 1993-96 growth. A logistic model with distinct intercept and slope for the two periods was fit to the data. Quasilikelihood methods for model fitting to control for temporal clustering effects were used..$^{12}$ The fitted model was used to test the impact of the helmet law with respect to the change in trend in helmet use in 1997-2000 compared with that in 1993-96. In particular, the increase of helmet use in 1997 beyond what is projected from the 1993-96 growth is attributable to the helmet law. The log odds ratio for this excess increase was 1.9147 , with a $95 \%$ CI of 1.1 to 2.7 . This illustrates the significance of the law. Hillsborough County crash data also showed an average of $28 \%$ of children with no recorded injures wore helmets, whereas an average of $8 \%$ with recorded injuries wore helmets.

The data in table 2 also show a corresponding decline in rates of motor vehicle related bicycle injuries. The average rate of injuries was approximately 1.5 times greater during the pre-law years (1993-96) than in the post-law years (19972000) (69.65 $v 45.43$, respectively). Various trend tests revealed a statistically significant decrease of the injury incidence over the period of $1993-2000(\mathrm{p}<0.018) .{ }^{13}$ The decline was slightly more significant $(\mathrm{p}<0.014)$ when comparing the incidences in the two periods before (1993-96) and after law enactment (1997-2000). Data were adjusted for possible clustering effects. Test statistics based on quasilikelihood gave a p value of less than 0.00001 , illustrating a highly significant reduction in the reported injury rate over and above any natural decline in rates. ${ }^{12}$

\section{Key points}

- Trend tests utilizing logistic models showed that observed bicycle helmet use of children, ages 5-13 in Hillsborough County, Florida has significantly increased since passage of Florida's bicycle helmet law for children under the age of 16.

- Trend tests also show that there has been a significant decline in motor vehicle bicycle rider injuries in children during the post-law (1997-2000) years compared with the pre-law years (1993-96).

- There has not been an observed decrease in the number of children riding bicycles in our yearly observations nor a seasonal nor tourist effect.

- Helmet use was shown to be lower in child bicyclists in motor vehicle crashes who were injured than in those children not injured.

- We believe measures should be acted upon now to sustain increases in children's bicycle helmet use.

To illustrate the association of the law and injury rate, we also fit a logistic model to the injury data. The model represents a decreasing trend, with a parallel shift downwards that occurred in the 1997-2000 post-law period. This shift is represented by the change of intercept from that for 1993-96 to that for 1997-2000. The log odds ratio was -0.6734 with the $95 \%$ CI of -1.3 to -0.02 .

Data from 1996-2000 permitted review of patterns of reported possible injury, non-incapacitating injury, incapacitating injury, and fatalities and helmet use. Results were consistent throughout the years showing that the overall mean number of non-fatal injuries reported was greatest for the non-incapacitating category (57.6\%), followed by an approximate mean of $21 \%$ for other non-fatal categories. Reported helmet use was on average only slightly higher for the non-incapacitating category $(9.8 \%)$ than the other two categories (about 6\%). Only seven deaths were reported from 1996-2000 and helmet use for the victims was reported to be $40 \%$. However, due to the small numbers of deaths over the years, inferences about the role of helmets are limited.

In terms of state data, for $0-14$ year olds, the average motor vehicle bicycle related injury rate declined from 73.3 in the pre-law years (1993-96) to 41.8 in the post-law years (19972000), reflecting findings in Hillsborough County. The average state injury rate for individuals 15 years and older only declined from 42.3 during the pre-law years to 31.3 during the post-law years, showing greater efficacy for the $0-14$ year olds, the primary target group.

\section{DISCUSSION}

The helmet law may have contributed to the increase in helmet use among children in Hillsborough County and there has been a simultaneous decrease in bicycle rider injuries from motor vehicle crashes in this county and statewide. However, the county has used complimentary strategies to increase helmet use such as school programs, bicycle safety rodeos, and helmet giveaways to lower income children and these efforts may also impact the decline. Data still show that the greatest change in helmet use occurred after passage of the law. No decline in children riding bicycles was seen in our yearly observations, and no seasonal effect with helmet use or crash data was found.

\section{Study limitations}

Although some riders observed may be tourists or other nonyear round residents, the primary reliance on observations in school settings minimizes this concern. The legislation applied to children under age 16, but injury data are limited to those age $0-14$. The rate reflects only injuries sustained from reported involvement with a motor vehicle, whereas more bicycle injuries occur in non-traffic settings. Most non-fatal 
bicycle injuries are due to falls, which often are unreported ${ }^{14}$ and can possibly lead to traumatic brain injury. In addition, use of Department of Transportation data may yield subjective results since the determination of the injury category, crash characteristics, and helmet usage is made by the officer at the crash scene. Police receive various levels of training and therefore interpretations may differ. Although police reporting bias may exist, this does not appear to be the case with helmet use and injury severity since nearly the same percentage of helmet use was reported for the least severe injury category (possible) as the most severe (incapacitating).

Finally, injuries due to motor vehicle crashes are reported for all categories, not just head and neck. However, helmet use was lower in children injured than those not injured. We believe measures should be taken now to sustain increases in bicycle helmet use and to reinforce helmet wearing as a normative behavior.

\section{ACKNOWLEDGEMENT}

The authors would like to thank Drs Zhu and Perrin at the University of South Florida College of Public Health for their statistical expertise during this project.

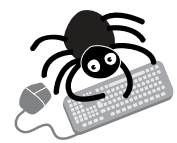

The fitted logistic models for children's bicycle helmet use and injury rate are found on our website at www.injuryprevention.com/supplemental
Authors' affiliations

K D Liller, J Nearns, M Cabrera, R McDermott, University of South Florida College of Public Health, Tampa, Florida

B Joly, Maine Center for Public Health, Augusta, Maine

$\checkmark$ Noland, University of Florida, Gainesville, Florida

\section{REFERENCES}

1 Attewell, RG, Glase K, McFadden M. Bicycle helmet efficacy: a meta-analysis. Accid Anal Prev 2001;33:345-52.

2 Cote TR, Sacks JJ, Lambert-Huber DA, et al. Bicycle helmet use among Maryland children: effect of legislation and education. Pediatrics 89:1216-20.

$3 \mathrm{Ni} \mathrm{H}$, Sacks JJ, Curtis L, et al. Evaluation of a statewide bicycle helme law via multiple measures of helmet use. Arch Pediatr Adolesc Med 1997:151:59-65.

4 Rodgers GB. Effects of state helmet laws on bicycle helmet use by children and adolescents. Inj Prev 2002;8:42-6.

5 Bicycle Helmet Safety Institute. Available at: hittp://www.bhsi.org/ mandator.htm.

6 Kanney D, Scheiber RA, Pryor V, et al. Effectiveness of a state law mandating use of bicycle helmets among children: an observational evaluation. Am J Epidemiol 2001;154:1072-6.

7 Posner M. Preventing school injuries. New Brunswick, NJ: Rutgers University Press, 2000: 77-84.

8 DiGuiseppi CG, Rivara FP, Koepsell TD, et al. Bicycle helmet use by children: evaluation of a community-wide helmet campaign. JAMA 1989;262:2256-61.

9 Liller KD, Knowles A, McDermott RJ. Bicycle helmet use among children in Hillsborough County, Florida. Journal of Health Education 1995:26:292-6.

10 Safe Kids Campaign. Available at: http://www.safekids.org.

11 McDermott RJ Sarvela PD. Health education measurement and evaluation. 2nd Ed. Madison, Wl: WCB McGraw Hill, 1999: 224-42. 2 McCullagh P. Nelder J. Generalized linear models. London: Chapman and Hall, 1989 .

13 Zhu Y, Fung K. Statistical methods in developmental toxicity risk assessment. In: Chang L, ed. Toxicology risk assessment. New York: Marcel Dekker, 1996: 413-46.

14 Harborview Injury Prevention and Research Center. Bicycle injuries-scope of the problem. Available at: http:// depts.washington.edu/hiprc/childinjury.

If you can't find what you are looking for in Injury Prevention you can extend your search across many of the more than 300 journals available for selection. You can restrict your search to specific subject areas

(eg, clinical medicine, basic research), or select specific journals, or search all available titles.

www.injuryprevention.com 